\title{
Mister Russland Arktis?
}

\author{
Vjatsjeslav Zilanov (oversatt av Svetlana Petrovna Jakobsen \& Reidar Jakobsen) \\ Oslo: Vidarforlaget 2018 \\ 281 sider. ISBN 9788279902867
}

Omtalt av Filippa Sofia Braarud [MA International Security, sikkerhetsanalytiker, filippasbraarud@gmail.com]

Vjatsjeslav Zilanovs Mister Russland Arktis? setter søkelyset på et sett svært dagsaktuelle problemstillinger, nemlig hvem som eier hvilke ressurser i Arktis, og hvor grensene mellom de arktiske statene går. Zilanov har selv lang erfaring med fiskeriforhandlingene mellom Norge og Russland/Sovjetunionen, blant annet som visefiskeriminister og medlem av en rekke ekspertgrupper som var sentrale $i$ forhandlingene med Norge fra 1973 og frem til delelinjeavtalen ble undertegnet i 2010. Zilanov skildrer sine mange møter med norske forhandlere gjennom disse tiårene, og boken gir spennende innsikt i Jens Evensens og Arne Treholts roller i utformingen av blant annet gråsoneavtalen i 1978.

Zilanov tar for seg det russiske perspektivet og dedikerer store deler av boken til å beskrive hvordan han mener den politiske utviklingen gjennom de siste tiårene har skadet Russlands interesser. Særlig tar han vanlige russiske fiskere i forsvar, fordi han mener de har måttet lide uforholdsmessig mye under en rekke russiske regjeringers uheldige utenrikspolitikk. Han fremstiller mange av hendelsesforløpene rundt og etter signeringen av en rekke internasjonale avtaler og traktater i et nærmest melankolsk lys, med en bismak av skuffelse og resignasjon over de havområdene som Zilanov anser at Russland har "tapt» de siste hundre årene. Zilanov bruker store deler av boken på å beskrive hvordan Russland, og i sin tid Sovjetunionen, har ført en politikk som han mener har gjort at russerne urettmessig har mistet store deler av sine fiskeområder til sine arktiske naboer.

Zilanov begynner med å beskrive hvordan det hele startet, nemlig med at Russland i 1867 signerte konvensjonen som ga USA suverenitet over Alaska - en avtale han beskriver som «utvilsomt et av de groveste strategiske feiltrinnene begått av russiske politikere» - og som banet vei for at fiskeområder i Beringhavet også ble amerikanske (s. 87). Forhandlingene om disse ble avsluttet i 1990, da store deler av Beringhavet og Tjuktsjerhavet ble avgrenset som amerikanske havområder en delelinje som blir fikk tilnavnet «Sjevardnadzes landssvikerlinje» av de russiske fiskerne (s. 82). Zilanov nevner også at Sovjetunionen og Russland forgjeves har hevdet bruksrett på Svalbard i århundrer, for til slutt å ha blitt tvunget til å signere 
Svalbardtraktaten i 1920 i bytte mot at den nylig etablerte Sovjetunionen skulle bli anerkjent av de andre signaturlandene. Alle disse avtalene blir i boken beskrevet som en rekke særs ugunstige løsninger for russiske fiskere.

Hovedfokuset i boken er likevel på signeringen av delelinjeavtalen mellom Norge og Russland i 2010, som Zilanov mener parkerte et historisk argument for russiske sedvanerett på fiskeri- og kommersiell aktivitet i området rundt Svalbard. Delelinjeavtalen blir beskrevet som nærmest en hestehandel som urettmessig "ga bort» 80000 kvadratkilometer russiske fiskeområder til Norge, angivelig i bytte mot et hypotetisk petroleumssamarbeid i Sjtokmanfeltet helt nord i Barentshavet (s. 166). Han beskriver hvordan mange russere anså delelinjeavtalen som et stort landssvik av en regjering som ikke lenger satte vanlige folk først. Det er dette som er det gjennomgående temaet i boken. Den tar for seg, skritt for skritt, hvordan den alminnelige russiske fiskeren gradvis har mistet stadig flere av sine rettigheter til sine opprinnelige fiskeområder for å gi drahjelp i utenrikspolitikken. Zilanov setter tydelige spørsmålstegn ved en rekke av myndighetenes avgiørelser, og han legger avslutningsvis ved en liste over 14 tiltak som han mener de russiske myndighetene må iverksette for å giøre et forsøk på å rette opp sviket delelinjeavtalen utgjorde for den russiske befolkningen.

Til tross for sine kritiske blikk på både norsk og russisk politikk skildrer Mister Russland Arktis? i detalj hvordan varme vennskap og dyp respekt gradvis oppsto mellom de russiske og norske forhandlerne gjennom de mange forhandlingsmøtene $\mathrm{i}$ denne perioden. Disse historiene og ofte hjertevarmende anekdotene er nesten grunn nok i seg selv til å lese boken, fordi de på mange måter beskriver det gode naboskapet mellom Norge og Russland - et forhold basert på respekt og felles historie, geografi og en forkjærlighet for et lystig lag folk imellom, uavhengig av tidvise politiske uoverensstemmelser. I så måte preges boken av en smittende optimisme om hvordan gode fiskeriavtaler tjener som eksempler til etterfølgelse. Spesielt trekker Zilanov frem den blandede norsk-russiske fiskerikommisionen, som til dags dato setter fiskekvoter og utfører inspeksjoner av rov- og overfiske i Barentshavet for å sikre bærekraftige fiskebestander. Takket være denne har Norge og Russland - og Sovjetunionen i sin tid - klart å opprettholde en av de best forvaltede fiskebestandene i verden.

Mange av bokens temaer er svært dagsaktuelle, særlig siden vi lever i en tid preget av økosystemers kollaps og global politisk polarisering, og stadig flere etterspør bærekraftige mellomstatlige løsninger for ressursforvaltning. Boken er også særlig relevant når vi nå nærmer oss Svalbardtraktatens hundre årsjubileum i 2020. Den setter søkelyset på en rekke problemstillinger vedrørende norske rettigheter på Svalbard, som Norge muligens må være forberedt på å måtte forsvare $i$ fremtiden. Når det gjelder suverenitetshevdelse, tar den for seg tilsvarende tematikk som også dommen som falt i Norges Høyesterett den 14. februar i år, tok stilling til, nemlig om snøkrabbefisket rundt Svalbard, og derfor hvem som har rett til å bruke samt begrense bruken av ressursene på sokkelen rundt Svalbard. Avslutningsvis er det verdt å nevne at til tross for en rekke kritiske bemerkninger, viser boken også til en rekke gode eksempler på hvor stort handlingsrommet kan bli når respekten og evnen 
til å lytte er gjensidig, og når man setter seg inn i motpartens behov og bekymringer. Og kanskje er det nettopp det som gjør det så spesielt nyttig og verdifullt at boken nå er tilgjengelig på norsk - nemlig at vi gjennom den kan søke dypere innsikt i våre russiske naboers verdenssyn. 